\title{
LITERASI INFORMASI SEJAK DINI: PENGETAHUAN BARU BAGI ANAK USIA DINI
}

\author{
Yasir Riady \\ e-mail: yasir.riady@gmail.com \\ UPBJJ Universitas Terbuka Jakarta
}

\begin{abstract}
Abstrak: Masa keemasan pada anak usia 0 hingga 8 tahun merupakan suatu fase dimana anak mulai mengenal dunia dan menentukan bagaimana akan tumbuh, berkembang, hidup dan beraktivitas dalam menjalani kehidupannya. Masa ini berlangsung hanya sekali dalam kehidupan manusia, kecepatan pertumbuhan serta perkembangan yang sangat pesat yang mencapai sekitar 50\% kapasitas kecerdasan manusia telah terjadi ketika usia 4 tahun, $80 \%$ terjadi ketika usia 8 , dan 100\% ketika anak mencapai usia 8 - 18 tahun, artinya rentan usia tersebut merupakan usia dasar dalam perkembangan anak. Salah satu hal yang harus dipahami dan dimengerti untuk perkembangan anak usia dini adalah kemampuan literasi informasi yang harus sudah dikembangkan sejak dini, hal ini dapat membantu anak untuk memiliki keterampilan dan kemampuan dalam mengidentifikasi, menemukan, mengevaluasi, menyusun dan secara efektif menciptakan pengetahuan baru, memanfaatkannya serta mengkomunikasikannya dalam rangkaian pemecahan masalah yang sedang dihadapinya. Tulisan ini memaparkan pentingnya literasi informasi sebagai tahapan awal bagi anak untuk perkembangan dalam pengetahuan barunya, penyelenggaraan pendidikan usia dini dengan melihat kualitas serta ditambah kemampuan literasi informasi dapat menjadikan pengetahuan awal bagi anak sehingga berkembang menjadi anak yang cerdas, bijak dan berhati mulia.
\end{abstract}

Kata-kata kunci : literasi informasi, anak usia dini, pengetahuan baru, Indonesia.

\section{EARLY INFORMATION LITERACY: NEW KNOWLEDGE FOR EARLY AGED CHILDREN}

\begin{abstract}
The golden age of children aged 0 to 8 years is a phase in which children begin to know the world and will determine how it will grow, develop, live and move on through life. This step of life will take place only once in human life, as well as the growth rate of rapid growth to reach about $50 \%$ the capacity of the human intellect has occurred when the age of 4 years, $80 \%$ occurred when the age of 8 , and $100 \%$ when the child reaches the age of 8-18 years, means such a vulnerable age in the elementary age child development. One of the things that must be understood for the development of early childhood literacy is the ability of information that must be developed early on, it can help children to have the skills and ability to identify, locate, evaluate, organize and effectively create new knowledge, use it and communicate it in a series of problem solving at hand. This paper describes the importance of information literacy as an initial stage for the child to progress in his new knowledge, the organization of early childhood education by looking at the quality and the added ability to make information literacy prior knowledge of the child so that the child develops to become intelligent, wise and noble.
\end{abstract}

Keywords : Information literacy, early childhood, new knowledge, Indonesia.

\section{PENDAHULUAN}

Perkembangan anak usia 0 hingga 8 tahun merupakan masa keemasan dimana anak mulai mengenal dunia dan menentukan bagaimana akan tumbuh, berkembang, hidup dan berkreasi dalam menjalani kehidupannya, masa ini hanya terjadi sekali dalam kehidupan dan berdampak luar biasa ketika anak itu beranjak dewasa serta anak juga akan mengalami kecepatan pertumbuhan dan perkembangan yang sangat pesat.

Masa ini merupakan suatu fase yang sangat baik untuk dapat memberikan pola dasar pada pendidikan anak agar berkembang sehingga ia dapat menjalankan dan memberikan yang terbaik dalam aktivitasnya ketika beranjak dewasa. Unsur-unsur yang sangat berpengaruh dalam perkembangan mereka orangtua, keluarga, masyarakat serta lingkungan dimana tumbuh 
dan berkembang.

Orangtua dan keluarga sebagai perantara langsung dan berhadapan dengan anak membentuk perkembangan awal bagi anak dan sebagai pondasi dasar pengembangan kemampuan fisik dan berbagai kecerdasan agar dapat berkembang secara optimal, ketika memasuki tingkat yang lebih luas seperti pada masyarakat maupun lingkungan dimana tumbuh dan berkembang, peranan ini lebih kepada pembentukan karakter dan kepribadian anak sewaktu ia bermain dengan teman sebayanya maupun ketika mulai memahami hal-hal baru yang ada di luar serta mencoba meniru maupun mengadopsi perilaku yang dilihatnya dalam aktivitas sehari-hari, intinya sebagai salah satu dari bagian yang hidup di keluarga, masyarakat dan lingkungan, sebaiknya kita harus dapat memberikan contoh yang baik bagi anak karena pada dasarnya seorang anak akan senantiasa mengikuti atau meniru apa saja yang ada disekitarnya, perkembangan inilah yang akan menjadikan modal bagi anak tersebut untuk dapat memasuki pendidikan formal.

Perkembangan tersebut memasuki satu fase pada situasi anak menyerap banyak informasi, pada fase tersebut pentingnya literasi sebagai langkah awal pengenalan pengetahuan dapat membantu anak dalam mengembangkan, inovasi dan kemampuan dasarnya, orangtua sebagai panutan dan juga pendidik baik di lingkungan formal maupun nonformal dapat memanfaatkan situasi ini dengan maksimal agar perkembangan anak di masa yang akan datang semakin baik dan dapat bertahan dari berbagai permasalahan yang akan dihadapinya.

Identifikasi permasalahan yang dibahas dalam tulisan ini adalah perkembangan keingintahuan dan kemampuan mendapatkan informasi di tengah kehadiran teknologi informasi dan komunikasi pada masyarakat yang sangat cepat, saat ini anak pada usia dini sudah dihadapkan dan diajarkan untuk dapat memiliki kemampuan dalam memilah dan memilih informasi yang dibutuhkan, orangtua, keluarga dan guru yang akan menjadi penentu dalam memberikan akses utama kepada anak, hanya saja hubungan dan aktivitas kehidupan bagi anak-anak saat ini mudah disajikan dalam telepon, film, video, radio, televisi dalam keseharian kehidupannya yang terkoneksi secara terpasang. Kehadiran dan pentingnya pengenalan literasi informasi diharapkan menjadi salah satu bagian untuk bisa memberikan dasar bagi anak dalam meniru dan memahami apa yang sebaiknya dilihat dan ditiru serta menjadikan anak sadar mengenai sumber informasi yang dapat diperolehnya sesuai dengan kebutuhannya.
Tulisan ini bertujuan untuk memberikan deskripsi dan gambaran secara umum mengenai pengetahuan baru dan awal untuk anak serta pengembangan informasi yang dibutuhkan, pengenalan literasi informasi sesuai dengan jenisnya dapat memberikan pengetahuan awal serta akses untuk setiap anak dalam bersosialisasi, berpartisipasi dan kebutuhan baik dalam belajar maupun dalam kehidupan seharihari serta bagaimana anak tersebut dapat menyadari informasi dan cara mendapatkannya.

Tulisan ini diharapkan dapat bermanfaat dalam memberikan pemahaman dan pengertian untuk perkembangan anak usia dini, melalui kemampuan literasi informasi yang sebaiknya sudah dikembangkan sejak dini, hal ini dapat membantu anak untuk memiliki keterampilan dan kemampuan dalam mengidentifikasi, menemukan, mengevaluasi, menyusun dan secara efektif menciptakan pengetahuan baru, memanfaatkannya serta mengkomunikasikannya dalam rangkaian pemecahan masalah yang sedang dan akan dihadapinya

Kebutuhan akan literasi informasi dapat dimulai sejak dini, anak dapat belajar, memahami dan melakukan kegiatan berdasarkan informasi yang di dapatkan, kebutuhan informasi anak sangat tinggi dan berkembang sesuai dengan umurnya, hal ini dapat dipastikan seorang anak akan banyak bertanya mengenai banyak hal yang ditemuinya, masyarakat yang disekitarnya harus dapat memahami hal ini serta juga bisa merespon keingintahuan anak tersebut sehingga kebutuhan informasinya dapat dipenuhi dengan baik, dengan demikian anak jadi memahami cara belajar yang baik dan benar, bersikap dan mengembangkan kemampuannya sebagai pengetahuan yang akan digunakan dalam kegiatan keseharian.

Para ahli neurologi meyakini bahwa sekitar 50\% kapasitas kecerdasan manusia telah terjadi ketika usia 4 tahun, $80 \%$ terjadi ketika usia 8 , dan $100 \%$ ketika anak mencapai usia 8 - 18 tahun (Endah : 2012), setiap harinya sebelum usia 4 tahun, perkembangan anak terjadi sangat cepat, keingintahuan yang dimiliki sangat tinggi dan hal baru yang akan ditemui setiap harinya akan berbeda, dia akan mempelajari berbagai macam hal dan mengadopsi apa yang ada di lingkungan sekitarnya, sehingga masa ini yang sangat baik dan aktif untuk bisa membentuk sebuah pribadi anak yang sempurna.

Pada tahun-tahun pertama kehidupan, otak anak berkembang sangat pesat dengan menghasilkan bertrilyun-trilyun sambungan yang memuat berbagai kemampuan dan potensi. Hal 
inilah yang melatarbelakangi pentingnya pendidikan yang tepat untuk dimulai pada anak sejak dini dan ditangan anak-anak inilah kelanjutan generasi bangsa ditentukan, pendidikan pada anak usia dini menjadi dasar dan pijakan dalam bertahan maupun memahami permasalahan yang dihadapinya.

Pendidikan bagi anak usia dini sebaiknya diimplementasikan ketika mulai berumur 0 tahun, karena semenjak lahir seorang anak memiliki berbagai kemampuan dan potensi genetik yang akan sangat baik sekali dan terasa manfaatnya di masa yang akan datang jika potensi tersebut diasah dan dikembangkan, namun pada kenyataanya banyak sekali para orangtua tidak menyadari hal tersebut, selain itu perkembangan ini juga memerlukan keadaan lingkungan yang memungkinkan agar dapat berkembang dan membantu pertumbuhannya dalam memahami diri, kepribadian, kemampuan, sikap, tingkah lakunya serta saraf motoriknya.

Orang tua juga mempunyai peran tersendiri, dengan mengembangkan potensi diri memperkaya ilmu pengetahuan dan informasi sehingga dapat memberikan hal yang terbaik sedini mungkin serta pengetahuan-pengetahuan penting lainnya yang dapat membuat orang tua menjadi pusat informasi dan edukasi awal yang baik bagi anak, selain itu dukungan juga sebaiknya tidak hanya dari pemerintah tetapi juga dari masyarakat hingga keluarga juga harus dapat memajukan pendidikan anak usia dini, karena masih sangat terbatasnya jumlah lembaga pendidikan atau program layanan pendidikan anak usia dini terlebih lagi di daerah, selain itu kesadaran orangtua untuk dapat mempercayakan layanan tersebut sebagai tempat yang tepat bagi anaknya juga diperhatikan agar orangtua dapat memahami pentingnya PAUD dan tidak segan untuk memberikan kesempatan kepada anaknya memperoleh pendidikan yang terbaik sedini mungkin.

Salah satu hal yang harus dipahami dan dimengerti adalah kemampuan literasi informasi, US National Commision on Library and Information Science mendefinisikan literasi informasi sebagai seperangkat keterampilan dan kemampuan seseorang untuk mengidentifikasi, menemukan, mengevaluasi, menyusun dan secara efektif menciptakan pengetahuan baru, memanfaatkannya serta mengkomunikasikannya dalam rangkaian pemecahan masalah yang sedang dihadapinya. Kemampuan ini sangat diperlukan meskipun untuk anak usia dini. Alasan kenapa literasi sangat penting (ALA : 2012) khususnya bagi anak yang masih berusia dini : (a) anak jadi mengerti cara belajar yang baik dan benar, (b) anak dapat mengembangkan kemampuan dasar dan dapat dikembangkan untuk menjadikan kegiatan belajar sebagai aktivitas yang menyenangkan, (c) anak dapat belajar menggunakan berbagai macam jenis informasi sesuai kebutuhannya dengan tepat dan tahu bagaimana mengaplikasikan dalam kehidupan sehari-hari, (d)anak dapat ditujukan dan diarahkan untuk bisa mandiri dan dewasa, (e) anak siap menghadapi beragam informasi yang dibutuhkan seiring dengan perubahan masa dan kurikulum , dan (f) anak disiapkan menjadi warga negara yang bertanggung jawab

Pengertian literasi informasi bisa diartikan dalam berbagai jenis definisi, Work Group on Information Literacy salah satu yang berasal dari California State University mencoba merumuskan pengertian literasi informasi sebagai kemampuan untuk dapat menemukan, mengevaluasi, dan menggunakan informasi dalam berbagai jenis dan format (California State University, 2001).

Pada usia dini, kita dapat mengajarkan dan memberikan informasi selama perkembangan anak dalam mencari informasi hingga anak tersebut beranjak dewasa, hal ini dikarenakan pencarian informasi membutuhkan kemampuan dan keahlian agar informasi yang didapatkan tepat guna dan juga dapat berkembang serta diarahkan dengan baik, beberapa hal yang harus diperhatikan, yaitu:

a. Dapat membuat pertanyaan, permasalahan, atau isu yang ada disekitar.

b. Menentukan informasi yang dibutuhkan untuk pertanyaan, permasalahan, atau isu disekitarnya.

c. Mengetahui tempat/letak dan menemukan informasi yang relevan

d. Mengorganisasikan informasi

e. Menganalisa dan mengevaluasi informasi

f. Mensintesa informasi

g. Mengkomunikasikan dengan menggunakan berbagai jenis teknologi informasi

h. Menggunakan perangkat teknologi untuk memperoleh informasi

i. Memahami etika, hukum, dan isu-isu sosial politik yang terkait dengan informasi dan teknologi informasi.

j. Menggunakan, mengevaluasi, dan bersifat kritis terhadap informasi yang diterima dari sumber informasi seperti media massa.

k. Menghargai bahwa keahlian yang diperoleh dari kompetensi informasi memungkinkan untuk belajar seumur hidup. 


\section{PEMBAHASAN}

Informasi mengenai penggunaan media literasi agar dapat memiliki kecakapan dalam literasi perlu dikembangkan, anak harus diberikan pelatihan literasi informasi secara tersusun seperti pada kurikulum, hal ini bisa berpengaruh ketika mereka beranjak dewasa.

Salah satu cara untuk memberikan pengenalan dasar mengenai literasi sekolah baik pra-sekolah maupun ketika sudah memasuki sekolah yaitu anak diberikan informasi dan keterampilan dalam memilih dan memilah informasi di internet, seperti website apa saja yang dapat dikunjungi baik untuk pendidikan, hiburan dan juga permainan, sehingga baik secara keilmuan maupun pengalaman awal dapat mengembangkan ilmu, teknologi dan komunikasi menjadi lebih baik hingga anak tersebut masuk ke perguruan tinggi.

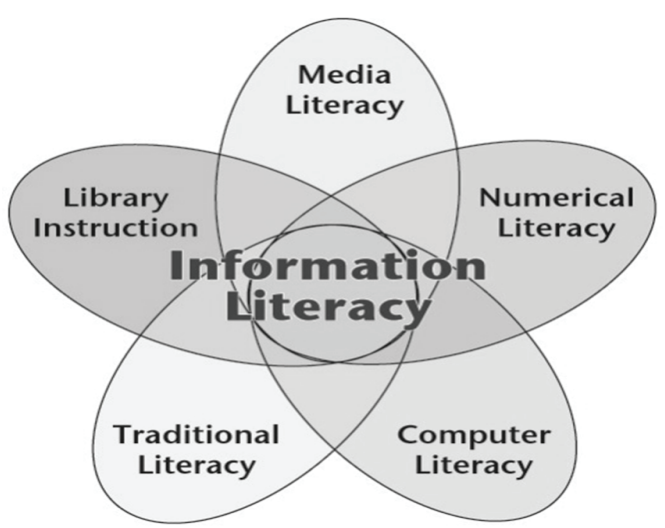

Gambar 1. Model literasi informasi

Sumber : kathleenmagann12.edublogs.org

Gambar 1 mendeskripsikan salah satu model literasi informasi, pada dasarnya kecakapan dasar informasi yang dapat dikenalkan ke anak baik literasi dalam media, komputer, perhitungan, budaya dan perpustakaan. Seluruh literasi informasi ini sangat berguna dan bermanfaat untuk anak ketika akan membutuhkan informasi apa saja yang di inginkan, hanya saja perlu arahan dan panduan dari orang tua maupun guru agar anak tersebut tidak mengakses informasi yang tidak di butuhkan.

Bagian yang tidak kalah penting mengenai pengertian literasi informasi pada usia dini yaitu mencakup elemen yang lebih luas (Doyle : 1992), seseorang berkembang dapat ditentukan sebagai individu yang menguasai literasi informasi jika memiliki : (1) menyadari kebutuhan akan informasi, (2) menyadari informasi yang akurat dan lengkap untuk menentukan tindakan, (3) mengidentifikasi sumber potensial dari informasi, (4) membangun strategi pencarian yang tepat, (5) mengakses sumber informasi dari berbagai teknologi, (6) mengevaluasi informasi, (7) mengorganisasikan informasi dan menggunakannya dalam kehidupan sehari-hari, dan (8) menggunakan informasi untuk menyelesaikan masalah.

Kemampuan ekonomi juga menjadi salah satu faktor penyebab dari terhambatnya perkembangan literasi informasi, jika melihat kenyataan pada saat ini, perbedaan letak dan fasilitas antara kota dan daerah menjadi salah satu hambatan lain, mengingat banyaknya fasilitas yang lengkap tidak sebanding dengan fasilitas yang dimiliki di perkotaan. Literasi informasi juga membutuhkan biaya yang tidak sedikit, namun berdampak cukup besar di masa yang akan datang.

Seorang anak dapat dikatakan mampu dan mengikuti perkembangan dalam literasi informasi jika dapat menentukan sifat dan cakupan informasi yang dibutuhkan, selain itu anak tersebut dapat mengidentifikasi kebutuhan dan jenis informasi dari sumber-sumber yang dapat dicari.

Metode pencarian informasi oleh anak umumnya berbeda-beda, ada yang menelusur sendiri dan menjadikan pengalaman, ada yang bertanya kepada teman, guru maupun orang tuanya dan ada juga yang melihat seperti di televisi maupun internet, alat komunikasi seperti telepon genggam dan tablet juga dapat membantu dalam pencarian informasi yang ingin diketahui oleh anak namun tetap harus diberikan perhatian dan pengarahan.

Sulistyo Basuki (2013) memetakan bahwa Jenis literasi informasi terbagi atas lima jenis, inti dari pembahasan tulisan ini mengenai jenis literasi yang dapat digunakan dalam perkembangan anak yaitu :

\section{A. Literasi visual}

Literasi visual artinya kemampuan untuk memahami dan menggunakan citra, termasuk kemampuan untuk berpikir, belajar, dan mengungkapkan diri sendiri dalam konteks citra. Litertasi visual ini merupakan salah satu jenis yang banyak sekali diterapkan oleh anak pada usia dini. Secara umum literasi visual adalah kemampuan untuk memahami serta menggunakan citra visual dalam kehidupan sehari-hari. Literasi visual mencakup integrasi pengalaman visual dengan pengalaman yang diperoleh dari indera lain seperti apa yang didengar, apa yang dibau, apa yang dikecap, apa yang disentuh serta apa yang dirasakan. Kompetensi literasi visual memungkinkan seseorang untuk memilah serta menafsirkan berbagai tindakan visual, objek dan atau 
simbol. Dari situ, seorang anak dapat berkomunikasi dengan orang lain, mendapatkan pengetahuan dan bertindak terhadap apa yang difikirkannya.

\section{B. Literasi media}

Literasi media merupakan kemampuan seseorang untuk menggunakan berbagai media dalam mengakses serta menghasilkan informasi untuk berbagai kebutuhan. Pada kehidupan seharihari, seorang anak akan sangat dipengaruhi oleh media yang ada di sekitarnya berupa televisi, film, radio, musik terekam, surat kabar dan majalah, alat komunikasi dan sebagainya. Penggunaan media yang terpasang dengan internet sangat mudah diakses serta memberikan pengetahuan informasi yang tidak terbatas.

Literasi media mencakup tiga bidang, yaitu literasi media yang memiliki akses ke media, memahami media dan menciptakan atau mengekspresikan diri sendiri dengan menggunakan media. Pengenalan literasi informasi membuat anak mempunyai kemampuan dalam menggunakan fungsi dan kompetensinya untuk memanfaatkan informasi yang dibutuhkannya. Ketika anak sudah memiliki akses, maka akan mencoba memiliki kemampuan untuk memahami atau menafsirkan isi informasi dan akan bersikap kritis terhadap informasi tersebut, terakhir anak tersebut akan menciptakan dan berinteraksi dengan media, seperti berkomunikasi maupun mendiskusikan dengan orang tua, keluarga atau teman-temannya.

\section{Literasi komputer}

Literasi komputer artinya kemampuan seorang anak untuk dapat menggunakan dan mengoperasikan perangkat komputer secara efektif dan efisien untuk memperoleh informasi. Literasi pada komputer sudah berbeda era dan zamannya, saat ini seorang anak dapat dengan mudah belajar dan menggunakan komputer tanpa harus khawatir akan adanya kerusakan maupun bisa mengakses secara maksimal dengan belajar sendiri untuk penggunaan dan pengoperasiannya. Saat ini banyak sekali perangkat komputer yang dapat digunakan baik personal komputer, laptop, notebook, serta alat komunikasi pintar yang sudah memiliki kapasitas seperti perangkat komputer pada gadget, tablet dan handphone.

Seorang anak tidak harus memiliki keahlian dan kemampuan khusus untuk bisa menguasai literasi komputer, biasanya anak akan melihat, mencoba dan mengeksplorasi perangkat tersebut hingga mahir, serta memaksimalkannya dalam memenuhi kebutuhan informasinya.

\section{Literasi jaringan}

Literasi jaringan merupakan literasi dalam menggunakan jaringan digital secara efektif, hal ini bisa didatangkan dengan adanya koneksi Internet. Seorang anak yang memiliki akses internet yang biak dapat dengan mudah menelusuri berbagai informasi yang di butuhkan, hanya saja peran orang tua, keluarga, tutor dan guru sangat penting untuk bisa membatasi literasi jaringan yang mana sesuai dengan porsi anak dan yang tidak boleh diakses. Pada tahapan jenis literasi ini, seorang anak sudah dapat memahami bagaimana informasi dihasilkan, dikelola, tersedia, dan dapat menelusuri informasi dari jaringan dengan menggunakan berbagai alat, serta mengkombinasikan dengan berbagai sumber, menambahnya atau meningkatkan nilai informasi dari situasi tertentu.

\section{E. Literasi kultural}

Literasi kultural artinya pengetahuan dan pemahaman tentang tradisi, kepercayaan, simbol dan ikon, perayaan dan sarana komunikasi sebuah negara, agama, kelompok etnik atau suku yang dapat berdampak terhadap penciptaan, penyimpanan, penanganan,komunikasi, preservasi serta pengembangan pengetahuan anak. Literasi kultural merupakan faktor budaya yang dapat berdampak terhadap penggunaan media oleh anak. Dampak itu dapat menjadi positif maupun negatif. Penyebaran televisi misalnya berdampak hilangnya permainan anak-anak secara tradisional. Pada sisi lain, penyebaran telepon seluler, televisi dan komunikasi secara online terjadi sebagai hasil kemampuan penduduk lokal untuk mengakui, menerima dan mengadaptasi teknologi tersebut dalam budaya masing-masing.

Selain jenis literasi yang sudah dipaparkan di atas, kajian mengenai analisis pendidikan yang diberikan sebagai anak usia dini menunjukkan bahwa pentingnya kegiatan ini dilakukan dan dapat dikembangkan dengan membuatkan aturan dan pengetahuan informasi, hal ini bisa diberikan ketika anak mulai bersosialisasi, berpartisipasi, serta memiliki kebutuhan dan ketertarikan dalam belajar seiring dengan keingintahuan yang sangat besar. Mereka juga melihat bahwa anak-anak sekarang belajar tentang skill yang kompleks sesuai dengan tantangan yang ada, terlebih dari dunia internet, beberapa hal yang berkaitan dengan penyebaran literasi informasi adalah sebagai berikut :

Pertama, tingkat pendidikan orangtua, keluarga, guru atau tutor mempunyai pengaruh yang sangat penting terhadap tingkat kualitas anak, kualifikasi pendidikan yang baik dapat memberikan pemahaman dan kemampuan dalam menerjemahkan kebutuhan 
informasi yang dibutuhkan anak.

Kedua, tingkat kompetensi orangtua, keluarga, guru atau tutor mempunyai pengaruh yang penting terhadap perkembangan anak, penyelenggaraan pendidikan seperti PAUD yang dilakukan baik oleh pemerintah, penyelenggara (yayasan) maupun masyarakat harus tersentuh oleh manajemen pendidikan yang menekankan agar dapat memberikan pemahaman dan literasi informasi yang baik.

Pada akhirnya, harus dievaluasi informasi dan sumber yang digunakan oleh anak dilihat ide dan konsep yang anak sampaikan ketika mendapatkan informasi yang di butuhkan, kemudian menjelaskan, bertanya atau membandingkan pengetahuan baru yang didapatkannya melalui penelusuran informasi untuk dapat menyimpulkan sebuah permasalahan. Intinya, juga melihat bagaimana penggunaan informasi oleh anak tersebut, apakah anak tersebut akan mengkomunikasikan hasilnya dengan orang lain, atau hanya memahami dan melakukan dalam tindakan aktivitas sehari-hari.

\section{PENUTUP}

\section{Kesimpulan}

Masih sedikit serta terbatasnya pendidik dan tenaga kependidikan, penyuluhan, seminar maupun pelatihan menjadikan pelayanan pada bidang literasi informasi kurang maksimal, jika saja pelaksanaan program yang dibuat dalam khusus mengenai pembentukan literasi informasi baik formal maupun informal secara jelas, ruang lingkup kerja serta badan hukum yang melindungi, prosedur dan proses yang tidak terlalu sulit, infrastruktur pendukung baik pada sarana maupun prasarana yang tersedia, kurikulum yang dibuat untuk meningkatkan mutu dan relevansi perkembangan informasinya, pengelolaan yang berjalan sesuai dengan rencana serta pembiayaan dan dana yang mencukupi dapat dibentuk dan dilaksanakan, penulis yakin kemajuan dan kecakapan literasi informasi di Indonesia akan terealisasi dengan sempurna dan menjadikan anak-anak Indonesia sebagai anak yang cerdas, bijak, ceria, dan berakhlak mulia.

Program-program literasi informasi dapat mengatakan masyarakat kreatif, inovatif dan juga berpengetahuan tinggi, penggunaan akses yang baik dan merata menjadikan Indonesia sebagai negara yang dapat memenuhi kebutuhan informasi masyarakatnya dan merealisasikan masyarakat berpengetahuan tinggi dan memiliki literasi informasi yang baik, hal ini sebaiknya sudah bisa diperhatikan untuk anak-anak sejak dini, mengingat kemajuan teknologi dan informasi yang berkembang sangat pesat, kemudahan mendapatkan pengetahuan akan semakin terbuka lebar.

\section{Saran}

Penyelenggaraan pendidikan untuk anak usia dini merupakan satu bagian untuk dapat memajukan bangsa, kualitas penyelenggaraan dengan adanya pendidikan literasi informasi semenjak dini dapat dimulai dengan pengenalan terhadap informasi yang dibutuhkan dan juga perangkat yang ada di dalamnya.

Pada aspek general yaitu kepemimpinan, tenaga pendidik (kualifikasi dan kompetensi), sarana dan prasarana, pembiayaan dan peserta didik, proses perencanaan, pengkoordinasian. Kegiatannya juga mencakup terhadap pelaksanaan, pemasaran, monitoring dan evaluasi. Hal ini akan menciptakan suasana dan atmosfer pengetahuan awal dan baru bagi anak usia dini.

Pemerintah juga sebaiknya menyiapkan ruang baca atau akses informasi yang merata baik di kota maupun di daerah, sehingga kebutuhan akan informasi sebagai hak asasi dapat terpenuhi dengan baik, keberaksaraan informasi khususnya dari usia dini, hal ini dapat mengikis ketidaktahuan, kemiskinan, kemalasan dan memposisikan hal yang benar dan salah. Penerapan literasi informasi yang merata dan mendalam dapat memberikan kesempatan seluruh masyarakat Indonesia khususnya anak-anak di usia dini dalam memajukan bangsa ini di masa yang akan datang.

\section{DAFTAR PUSTAKA}

Association of School Librarians and Association of Educational Communications Technology.(1998). Information standars for student learning. http:// www.ala.org/ala/aasl/aas/proftools/informationpower/informationLiteracyStandards_final.pdf. (diakses tanggal 22 Oktober 2012).
Basuki, Sulistyo. (2013). Literasi informasi dan literasi digital (diakses tanggal 21 Desember 2013).

Bawden, D. (2001). Information and digital literacy: a review of concepts. Journal of Documentation, $57(2), 218-259$

Bawden, D. (2008). Origins and concepts of digital 
literacy. Dalam C. Lankshear\&M. Knobel (eds). Digital literacies : concepts, policies, and paradoxes. Pp:15-32. New Yok: Peter Lang

Doyle, Christina, (1992). Outcome measures for information literacy within the national education goals of 1990 : Final report of the National Forum on Information literacy.

Edublogs, information learning. http://kathleenmagann12.edublogs.orgAkses 22Januari 2013.

Endah.(2002) Kondisi Kesehatan dan Gizi Anak Usia
Dini di Indonesia, http://parentingislami.wordpress.com. (diakses tanggal 22 Oktober 2012).

Subhan, M., Tjahjono, S.,\& dkk. Pemikir pembangunan dalam Kompas, 27Juni 2008.

Oden, S. (2003). The development of social competence in children, http://www.ericfacility.net/ ericdigests/ed281610.html (diakses tanggal 22 Oktober 2012).

Riwayadi. Sinergi untuk pendidikan usia dini. http:// padangnewspendidikan.blogspot.com (diakses tanggal 22 Oktober 2012). 